\title{
Designing task-based syllabus for writing class
}

\author{
Hanna Sundari ${ }^{1, *}$, Rina Husnaini Febriyanti $^{1}$, Gustaman Saragih ${ }^{1}$ \\ ${ }^{1}$ English Education Department, UniversitasIndraprasta PGRI, Jagakarsa-Jakarta Selatan, Indonesia
}

\begin{abstract}
Writing is viewed as the most complex skill to learn and to teach. Beside learner factors, teacher, materials and syllabus may also affect the process of learning language as foreign language. Syllabus, in general, can be defined as a set of what is taught (content) and the way it is taught (procedure. This current research aims to design a task-based syllabus for writing class at university level. This study was conducted by qualitative descriptive design with 92 students and 4 lecturers as respondents. As part of research and development project in one private university in Jakarta, a developed task-based syllabus was based on need analysis and the principles of task-based language teaching. Students' proficiency levels are fair with sentence patterns and grammar as the most difficult aspects. Academic writing is more preferable orientation with the small portions of creative writing. Then, the developed task-based syllabus has been proposed for writing class which covers the components of goal (learning outcome), course description and objectives, a set of writing tasks, features of content focus and language focus and course evaluation. The developed syllabus, then, can guide the lecturers in designing lesson plan and selecting materials for writing class.
\end{abstract}

Keywords: syllabus design, task-based language, writing skill

\section{Introduction}

Writing, as one of productive language skills, is communicating messages in written symbols involving other micro skills [1]. Writing activity purposes to express ideas to the readers. In regards to writing in second/foreign language, Hedge formulated the competences achieved by language learners, including the use of rhetorical features in organizing information, the use of technical aspects and accuracy to avoid ambiguity, the use of accurate grammar and vocabulary, and competence in styles to meet the audiences context [2]. From a set of competences mentioned, teaching writing class, particularly in foreign language context, seems challenging and effortful. For these reasons, writing class should be well-planned and prepared by course designers.

Related to preparation, course planning has seemingly become an essential factor in teaching process. Designing course includes several items to do, such as developing syllabus, planning lesson, selecting materials, and preparing tests. Concerning to syllabus,

\footnotetext{
*Correspondingauthor:hanna.sundari@gmail.com/hanna.sundari@unindra.ac.id
} 
Nation [3] wrote that syllabus, as a part of curriculum, includes learning goals, content and sequence of materials, layout, and evaluation. Moreover, it describes systematic objectives and materials to be taught and achieved in a certain format. Syllabus also focuses on selected and specific contents [4]. For more practical definition, Ur [5] said that the characteristics of syllabus are a set of public document containing a list of systematic contents and process, with explicit learning goals, time, methods, and materials. According to Candlin, syllabus, different from curriculum, is more narrowly localized and based on what actually happens at the classroom level as teachers and learners apply [6]. Syllabus has function as "navigation mode" for both teacher and learners. In short, syllabus can be defined as a set of what is taught (content) and the way it is taught (procedure). Therefore, for the sake of effectiveness and success of teaching and learning process, designing syllabus is inevitable and unquestioned.

In designing language course syllabus,Krahnke has proposed several types of syllabi, such as structural-based, notional/functional-based, situational-based, skill-based, contentbased, and task-based syllabus [6]. The latter refers to a syllabus based on tasks given to the learners in order to perform tasks in target language [7]. Task-based syllabus is developed based on the principles of Task-based language teaching (TBLT). According to Feez, TBLT focuses on process rather than products in which learners engage and interact communicatively in activities and tasks [8]. Then, the tasks are gradually sequenced based on difficulty level. The given tasks facilitate learners to use language and promote meaningful communication.

Furthermore, in the notion of TBLT, task is variously defined among the experts. In very general term, Longsaid that a task is a piece of work undertaken for oneself or others, freely or for some rewards, such as painting a fence and dressing a child. This definition implies that task is seemingly a set of activity [9] in everyday life. From pedagogical view, Skehan wrote that tasks are activities in which meaning is as primary focus and resemblance to real-life language use [8]. In linguistic perspective, Ellisdefines task as a workplan requiring learners' pragmatic language process and linguistic resources in achieving an outcome either productive or receptive language activities [10].Then, Nunan summed up that task is a piece of classroom work involving comprehending, manipulating, producing or interacting in target language. In the other words, tasks refer to activities in the classroom involving communicative language use in which focuses on meaning by using learner's own linguistic resources to achieve language outcome related to real-life language use. Concerning to the syllabus, a TBLT syllabus designs a set of the tasks performed by learners within program. Moreover, Nunan suggested the syllabus includes two types of tasks: real-world tasks and pedagogical tasks [8]. The real-world tasks refer to an unrestricted, holistic everyday activities found everywhere; meanwhile, pedagogical tasks are restricted assigned tasks to achieve specific goals of learning [11]. Accordingly, real-world tasks can be as the source and model for pedagogical tasks as long as they are eligible and purposeful.

Related to research and effectiveness, the TBLT has attained extensive attention in the field of language teaching. In reading skill, studies by Mao [9] and Kumara, Padmadewi, and Suarnajaya [12] have proved the effective application of TBLT in reading comprehension. Moreover, Widayanti's [13] research and Kusnawati's [14] study found that writing ability in understanding writing process and writing skill has been increased through action research using TBLT. From Malaysia, study by Ahmed, Jamilah and Bidin [15] has also proved that TBLT gives significant effect on writing skills for university students. Then, comparative study by Tabar and Alavi [16] showed that Task-based writing provides learners with different opportunities for planning prior to performing written tasks of different levels of cognitive complexity. However, the study related to develop a taskbased syllabus as part of course program particularly for writing class in university context 
may be still limited. Indeed, in the matter of English language teaching system at university level, institutions have large opportunity and autonomy to design the system [17]. For these reasons, the current study aims at developing a task-based syllabus for writing class at university level.

\section{Methode}

The purpose of the current study is to design task-based syllabus for writing class at university particularly in English education major. The research was conducted by qualitative descriptive research design as a part of research and development for writing course design at one private university in Jakarta. The used instruments were questionnaire, worksheets and interviews by taking 92 university students and 4 lecturers in the stage of need assessment as well as expert reviews for the first draft developed-syllabus. The collected data in interviews were analysed qualitatively using themes and categories; meanwhile, descriptive data using percentage were taken from questionnaire. The writing worksheets were evaluated and scored based on the scoring rubric for writing essay by Alice Oshima ${ }^{[18]}$.

In designing syllabus, the researchers followed the steps in design and development of task-based syllabus by Long and Crookes ${ }^{[16]}$, as follow: 1) a comprehensive need analysis, 2) diagnosis of learner need, 3) identification of target tasks learners are preparing to carry out, 4) classification of target tasks into task types, 5) development/selection of pedagogical tasks for classroom use, 6) sequencing of pedagogical tasks to form a task-based syllabus. Besides, the need analysis applied the Graves's stages, including: 1) deciding what information to gather, when, from whom, and how, 2) collecting information, 3) interpreting the information and making decisions ${ }^{[19]}$.

\section{Results and discussion}

This present research purposes to design a task-based syllabus for writing class at university level. After analysing the collected data and conducting the steps of designing syllabus, the findings cover two main points: the results of need analysis and a developed task-based syllabus.

From the rating of self-assessment, the students' levels of writing are categorized as fair. It means that they believe that they are able to write in English; even thought, they also realize they may fall in to errors, ineffectiveness and inaccuracy of writing. This result support the survey analysis by Floris in which revealed that $51.4 \%$ of the respondents thought they had fair in language level as intermediate level learners [20]. Moreover, developing sentences in correct patterns and using grammar seem to be the most difficult writing practices. Composing sentences in the forms of simple, compound and complex looks quite challenging. This may be consistent to what Murray and Christison [2] said that "there is no evidence that simple sentences are easier to understand than compound and complex ones". In contrary, writing mechanism, using conjunctions, and developing topics and ideas are considered as the easiest practices. This indicates that the students have a lot of ideas to write; however, they feel hard to express them in appropriate grammar patterns.

Some interesting results come up from students' writing worksheet. They were assigned to write one essay in descriptive or narrative types. Most of them preferred descriptive writing. The topics they chose were various and attractive, such as my favourite food, my future husband, and why I like Gado-gado. Then, the ideas are fairly organized in the form of 5-paragraph essay. Nonetheless, the thesis statements are quite unclear and ineffective to depict the whole essay. Still, some lacks of S-V agreement, sentence patterns, 
tenses, conjunction, word selection and writing mechanism appear here and there. This fact may support the study by Hidayahin evaluating writing essay by TESL college students whose errors were mostly on S-V agreement, tenses, part of speech and vocabulary [21]. Moreover, concerning to activities and practices, individual work is more preferable than pair and group work. This result may be different from the study by Tutyandari [17]. She found that pair or group work was useful to encourage passive learners in writing class.

From the perspectives of importance and orientation of writing, students and lecturers agree that all micro skills mentioned are important in writing class. Nevertheless, the lecturers think that creative writing, such as writing poem, poetry and drama scripts is less important. Meanwhile, the writing orientation is addressedto academic writing with the small portion of other orientations to support academic achievement.Besides, the targeted competences in the course should be relevant and adaptive to the real-world language use. Related to the topic, local contents and values can also be included for instructional materials. This opinions support the study by Gunantar which showed that local cultural content has become the purpose of EFL teaching, combined with foreign culture [22].Moreover, materials and activities are gradually classified from simple to complex. Based on these gathered data of need analysis, the researchers then made some decisions dealt with the learner needs and identification and classification of tasks set on the developed task-based syllabus.

The components on the developed syllabus covers several items, such as goal of course (learning outcomes), course description and objectives, both general and specific, a set of writing tasks, features of content focus and language focus and course evaluation. These components are partially derived from the task components by Nunan [23][9]. Tasks requires specific components: goals, input data, activities and settings (classroom modes).The outcome of the course is to develop students' writing skills in the terms of producing various written texts with clear, appropriate, and effective logical structure in the forms of sentences, paragraphs, and essays creatively and confidently.

After that, writing course is then levelled into three categories: basic, independent, and proficient users.Basic level focuses on writing a series of sentences with simple connectors about personal/social life and around. Meanwhile, independent level practices to write a clear detailed text in a linear sequence related to subject field of interest in the form of paragraphs. At proficient level, students can write clear well-structured texts of complex subjects in the form of essays to support academic achievement. The levelling and its objectivesare quite determined by curriculum plan, learning outcomes and graduate profile constructed by university.

Afterward,tasks are identified, classified and sequenced according to the pedagogical objectives that have been formulated and the real-world tasksexist. The tasks are stated in "ing" form to express activities the students will actually perform in the class room as well as skills they have to achieve in the real-world language use.For example, giving comments and captions for photos/pictures/situations sounds task that people do in real world. Then, the pedagogical task in the classroom become writing caption and comment for photos/pictures/situations, with specific language goal. Therefore, the tasks students perform in the classroom are formulated to use the language both inside and outside the class. This may be consistent to what Skehan stated that one of the key characteristics of a task is there is some sort of relationship to comparable real-world activities [10].

The other components of syllabus are content focus and language focus. Content focus are materials discussed during the course in order to achieve the desired goals. Furthermore, the language focus are linguistic features discussed and practised to support students completing the tasks. Putting the grammatical linguistic features on the syllabus may support of what Nunan said. He wrote that, despite the fact that tasks involve 
communicative language use focusing on meaning rather than grammar, the form is still important. Meaning and form are highly interrelated. He also added that the grammatical knowledge is to express meaning and to enable the language user to express different communicative meanings [10].

The classroom setting is one of task specific components ${ }^{239}$. In the developed syllabus, the classroom settings are not explicitly stated as the component of the syllabus. However, the modes can bevariously applied in the settings of individual work, pair work, group work, and the whole class mode. The classroom mode is selected by considering several factors, such as levels, class size, the task difficulty and time allocation. This purposes to give a plenty room for syllabus user to make adjustment and adaptation to the class situation.

At the course evaluation, process assessment is adopted both during the lesson and at the end of it. Nunan wrote that task should have a sense of completeness and stand alone as communicative act [10]. The completeness can be seen and measured when the students perform the assigned task completely in the class in the terms of fluency, accuracy and meanings mostly for written work. The evaluation modes consist of task performance, participation (attendance), portfolio, and examinations.

\section{Conclusion}

The present study aims at designing a task-based syllabus for writing class at university level. After getting the learner needs, orientation and importance of writing course, the developed syllabus was designed based on the principles of task-based language teaching. It covers several components, such as goal of course (learning outcomes), course description and objectives, a set of writing tasks, features of content focus and language focus and course evaluation. Then, the teachers/lectures can use this syllabus for their writing courses. Moreover, it can guide them to design lesson plan and to find suitable and appropriate materials. Just like a map or navigation mode, syllabus gives direction and leads the user to the destination. However, not everything is explicitly stated in it. Adjustment and adaptation are still needed.

This research is supported by Ministry of Research, Technology and Higher Education of Indonesia through the schema of PenelitianProdukTerapan (PPT) 2017 No. 0428/K3/KM/2017. Moreover, we would like to say our gratitude to our colleagues in LPPM Indraprasta PGRI University Jakarta for their assistance and supports.

\section{References}

1. Spratt, M., Pulverness, A. \& Williams, M., The TKT Course (Cambridge University Press, 2011).

2. Murray, D. E. \& Christison, M., What English Language Teachers Need to Know Volume II: Facilitating Learning (Taylor \& Fancis e-Libaray, 2011). doi:10.4324/9780203846292

3. Nation, P. \& Macalister, J. Language Curriculum Design (Taylor \& Fancis e-Libaray, 2010).

4. Brown, J. D., The elements of language curriculum: A Systematic Approach to Program Development (Heinle \& Heinle Publisher, 1995).

5. Ur, P., A Course in Language Teaching: Practice and Theory (Cambridge University Press, 2009) 
6. Rahimpour, M. Current trends on syllabus design in foreign language instruction. 2, 1660-1664 (2010).

7. Richards, J. C., Curriculum Development in Language Teaching (Cambridge University Press, 2001)

8. Richards, J. . \& Rodgers, T., Approaches and Methods in Language Teaching. Cambridge University Press (Cambridge University Press, 2001). doi:10.1016/0346251X(87)90017-0

9. Mao, Z., Theory Pract. Lang. Stud., 2, 2430-2438 (2012).

10. Nunan, D., Asian EFL J. Quaterly, 8, 12-18 (2006).

11. Sanchez, A., IJES, 4, 39-71 (2004).

12. Kumara, G., Padmadewi, N. \& Suarnajaya, J. Pendidik. Bhs. Ingg., 1, (2013).

13. Widayanti, M. J. Lang. Circ. J. Lang. Lit. 6, 27-39 (2011).

14. Kusnawati,. Bhs. Sastra, 14, 93-108 (2014).

15. Ahmed, R. Z., Jamilah, S. \& Bidin, B., Open J. Mod. Linguist., 6, 207-218 (2016).

16. Tabar, N. A. \& Alavi, S. M. A Comparative Study of the Effects of Task-Based Writing under Different Pre-Task Planning Conditions on Intermediate EFL Learners ' Written Performance in Personal and Decision-Making Tasks. 5, 970-978 (2013).

17. Cahyono, B. Y. \& Widiati, U., The Teaching of English as a Foreign Language in Indonesia (State University of Malang Press, 2011).

18. Oshima, A. \& Hogue, A. Introduction to Academic Writing:Third Edition (Pearson Education, Inc, 2007).

19. Graves, K., TeacherSource, 308 (2000).

20. Floris, F. D, .K@Ta, 10, 53-62 (2008).

21. Hidayah, A. T., Int. J. Educ. Res., 1, 1-12 (2013).

22. Gunantar, D. A., Lang. Circ. J. Lang. Lit. 10, 141-151 (2016).

23. Jeon, I., English Educ, 60, 87-109 (2005). 